\title{
Nucleotide Pool Imbalance and Antibody Gene Diversification
}

\author{
Asim Azhar ${ }^{1}$, Nasim A. Begum ${ }^{2}$ D and Afzal Husain ${ }^{3, *(D)}$ \\ 1 Department of Biotechnology, Faculty of Life Sciences, Aligarh Muslim University, Aligarh 202002, India; \\ azharasim@gmail.com \\ 2 Department of Immunology and Genomic Medicine, Graduate School of Medicine, Kyoto University, \\ Kyoto 606-8501, Japan; nasim@mfour.med.kyoto-u.ac.jp \\ 3 Department of Biochemistry, Faculty of Life Sciences, Aligarh Muslim University, Aligarh 202002, India \\ * Correspondence: afzal.bc@amu.ac.in
}

check for updates

Citation: Azhar, A.; Begum, N.A.;

Husain, A. Nucleotide Pool

Imbalance and Antibody Gene

Diversification. Vaccines 2021, 9, 1050.

https: / / doi.org/10.3390/

vaccines 9101050

Academic Editor:

Giampiero Girolomoni

Received: 30 July 2021

Accepted: 17 September 2021

Published: 22 September 2021

Publisher's Note: MDPI stays neutral with regard to jurisdictional claims in published maps and institutional affiliations.

Copyright: (c) 2021 by the authors. Licensee MDPI, Basel, Switzerland. This article is an open access article distributed under the terms and conditions of the Creative Commons Attribution (CC BY) license (https:// creativecommons.org/licenses/by/ $4.0 /)$.

\begin{abstract}
The availability and adequate balance of deoxyribonucleoside triphosphate (dNTP) is an important determinant of both the fidelity and the processivity of DNA polymerases. Therefore, maintaining an optimal balance of the dNTP pool is critical for genomic stability in replicating and quiescent cells. Since DNA synthesis is required not only in genomic replication but also in DNA damage repair and recombination, the abnormalities in the dNTP pool affect a wide range of chromosomal activities. The generation of antibody diversity relies on antigen-independent V(D)J recombination, as well as antigen-dependent somatic hypermutation and class switch recombination. These processes involve diverse sets of DNA polymerases, which are affected by the dNTP pool imbalances. This review discusses the role of the optimal dNTP pool balance in the diversification of antibody encoding genes.
\end{abstract}

Keywords: dNTP; V(D)J recombination; SHM; CSR; antibody; SAMHD1

\section{Introduction}

Immunoglobulins (Ig) are proteins expressed by B lymphocytes in response to pathogens, vaccine candidates, or artificial synthetic antigens. An Ig is composed of two heavy (IgH) and two light (IgL) chains. In humans, IgH chains are encoded by heavy chain locus present on chromosome 14, whereas light chains are encoded by either Igk or Ig $\lambda$ chain loci that are present on chromosome 2 and chromosome 22, respectively. There are five isotypes for $\operatorname{IgH}$ chain $(\operatorname{Ig} \mu, \operatorname{Ig} \delta, \operatorname{Ig} \gamma, \operatorname{Ig} \varepsilon$, and $\operatorname{Ig} \alpha)$, whereas the $\operatorname{Ig} L$ chain has only two types (Igא and $\operatorname{Ig} \lambda)$. The $\operatorname{IgG}$ and $\operatorname{Ig} A$ isotypes are further divided into four $(\operatorname{Ig} \gamma 1, \operatorname{Ig} \gamma 2$, $\operatorname{Ig} \gamma 3$, and $\operatorname{Ig} \gamma 4)$ and two $(\operatorname{Ig} \alpha 1$ and $\operatorname{Ig} \alpha 2)$ subtypes, respectively [1]. The N-terminal regions of heavy and light chains show high sequence variability and constitute the variable $(\mathrm{V})$ region of the antibody. The $\mathrm{V}$ region of the IgH chain is formed by the joining of $\mathrm{V}_{\mathrm{H}}$ (variable), $\mathrm{D}_{\mathrm{H}}$ (diversity), and $\mathrm{J}_{\mathrm{H}}$ (joining) gene segments, whereas the $\mathrm{V}$ region of the IgL chain is formed by the joining of only $\mathrm{V}_{\mathrm{L}}$ and $\mathrm{J}_{\mathrm{L}}$ segments [2,3]. The heavy chain constant $\left(\mathrm{C}_{\mathrm{H}}\right)$ regions of $\operatorname{IgM}$, IgD, IgG, IgE, and IgA are encoded by $\mathrm{C} \mu, \mathrm{C} \delta, \mathrm{C} \gamma, \mathrm{C} \varepsilon$, and $\mathrm{C} \alpha$ exon clusters, respectively, whereas light chains constant $\left(\mathrm{C}_{\mathrm{L}}\right)$ regions, are encoded by constant region exons of IgK and $\operatorname{Ig} \lambda$ loci [4].

The generation of effective antibodies by lymphocytes requires both antigenindependent and antigen-dependent diversification of Ig genes during the maturation of $B$ lymphocytes [1]. Antigen-independent rearrangements of germline V, D, and J segments of the Ig genes generate the primary antibody repertoire. The diversity of this repertoire is contributed by both the combinatorial diversity that results from the choices of germline $\mathrm{V}, \mathrm{D}$, and J gene segments and junctional diversity, which arises as a result of imprecise end-joining of germline segments [1]. However, the antibody repertoire produced by V(D)J recombination alone is not diverse enough to generate high-affinity antibodies against a wide range of antigenic challenges that an individual may encounter in a lifetime. Therefore, 
the repertoire of B-lymphocytes is further diversified following their encounter with antigens. The antigen activation of $B$ lymphocytes induces the expression of activation-induced cytidine deaminase (AID), an enzyme that is responsible for somatic hypermutation (SHM) and class switch recombination (CSR) of the immunoglobulin genes $[5,6]$. The processes of CSR and SHM engrave antibody memory, a critical requirement for humoral immunity, into the immunoglobulin genes [7].

The availability and adequate balance of deoxyribonucleoside triphosphates (dNTPs) are critical not only for DNA replication but also for DNA repair, and recombination [8-10]. The imbalances in the intracellular concentrations of dNTPs outside their normal ranges are closely associated with genomic instability, an inherent property of most human cancers. The dNTP pool imbalance affects genomic stability by affecting the rate of DNA synthesis and its fidelity during DNA replication, DNA repair, and recombination [8-12]. The DNA in our cell is subjected to various mechanical, chemical, and physical stress, resulting in the point mutations and formation of single- or double-strand DNA breaks (SSB or DSB). In addition, DNA breaks are also formed during physiological processes such as meiotic recombination, rearrangement of immunoglobulin gene segments, transposition of mobile elements, and integration of viral DNA into our genome [13]. As DNA repair involves various DNA polymerases, the dNTP pool imbalance affects DNA damage, repair, and mutagenesis. In this review, we specifically discuss the role of the optimal dNTP pool in the somatic hypermutation and recombination of antibody encoding genes.

\section{Cellular Nucleotide Pool and Its Regulation}

The de novo biosynthesis of dNTPs involves the reduction of ribonucleoside diphosphates (NDPs) to deoxyribonucleoside diphosphates (dNDPs), which upon phosphorylation yield dNTPs. This rate-limiting reduction of NDP to dNDP is catalyzed by an allosteric enzyme ribonucleotide reductase (RNR), a hetero-tetrameric enzyme composed of two large $\alpha$-subunits and two small $\beta$-subunits (Figure 1) [14]. The large subunit is encoded by the RRM1 gene, whereas the two closely related isoforms of the small subunit are encoded by RRM2 and RRM2B genes. The cellular levels of dNTPs highly fluctuate during the cell cycle, being highest in the S phase and lowest in the G1 phase. Consistently, the activity of RNR, which is tightly regulated by transcriptional, post-transcriptional, and allosteric controls, is restricted to S, G2, and M phases and is eliminated from the G1 phase of the cell cycle. The $\beta$-subunits contain iron-oxygen centers that are essential for the communication with catalytic sites on the $\alpha$-subunits. In addition to NDP-binding catalytic site, the $\alpha$-subunit also contains the allosteric activity site and the substrate specificity site. The binding of nucleotides to allosteric sites not only affects the activity of RNR but also regulates its substrate specificity, which is critical for the maintenance of nucleotide pool balance. The activity site responds to ATP or dATP to adjust the enzyme's overall activity, whereas the specificity site responds to dATP, dGTP, and dTTP to adjust the specificity for the four NDP substrates to produce a balanced amount of all four dNTPs [15-17]. The binding of dATP inactivates RNR by converting an active hetero-tetramer to an inactive hetero-octamer, whereas the binding of ATP stimulates RNR activity for all four NDPs [15-17]. Although the RRM1 subunit is constitutively expressed throughout the cell cycle, the expression of the RRM2 subunit is highest during the $\mathrm{S}$ phase, which boosts the activity of RNR in S, G2, and $\mathrm{M}$ phases of the cell cycle $[18,19]$.

In addition to de novo synthesis, nucleotide salvage pathways also contribute to the dNTP pool. Salvage pathways convert bases and nucleosides from nucleic acid degradation or exogenous sources back to nucleotides (Figure 1) [20]. Purines are salvaged through the action of adenine phosphoribosyltransferase (APRT) and hypoxanthine-guanine phosphoribosyltransferase (HGPRT). APRT and HGPRT adds phosphoribosyl pyrophosphate to adenine and guanine, resulting in the formation of adenine monophosphate (AMP) or guanine monophosphate (GMP), respectively. The addition of 2-deoxy-alpha-D-ribose 1-phosphate to thymine by thymidine phosphorylase leads to the formation of thymidine, which is converted to thymidine monophosphate (TMP) by thymidine kinase. The cytidine 
and deoxycytidine nucleosides are salvaged either through their deamination to uridine and deoxyuridine or by direct phosphorylation by uridine/cytidine kinase to cytidine monophosphate (CMP) or deoxycytidine monophosphate (dCMP).

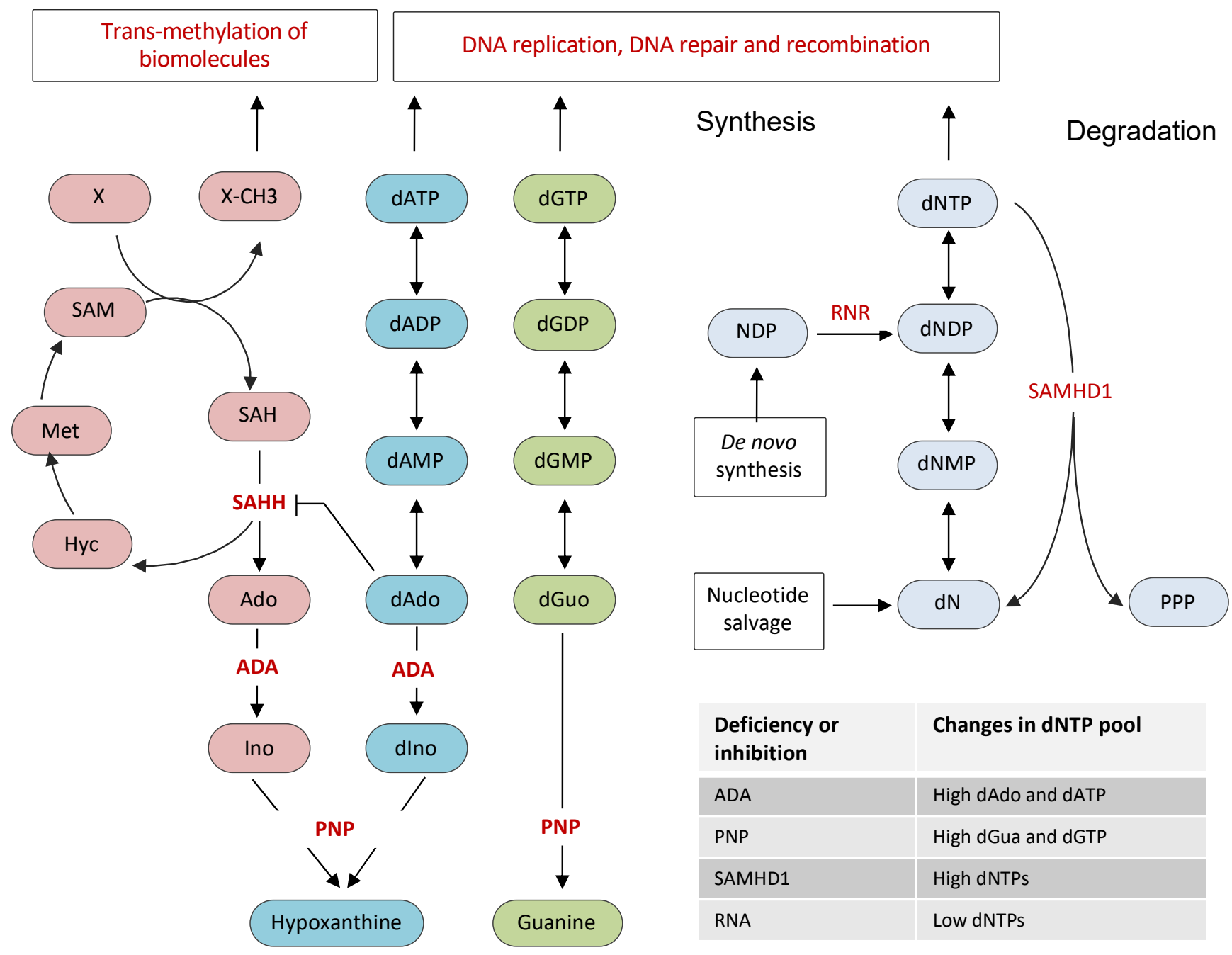

Figure 1. Nucleotide metabolic pathways associated with antibody gene diversification. The optimal dNTP pool is determined by the balance between de novo synthesis, consumption of synthesized nucleotides, and their degradation. RNR is the key enzyme that provides the balanced supply of dNTPs by converting ribonucleotides to deoxyribonucleotides. The nucleotide salvage pathways contribute to the dNTP pool by converting nitrogen bases and nucleosides back to nucleotides. SAMHD1, a dNTP hydrolase, degrades nucleotides to maintain low levels of dNTPs in the G1 phase. ADA and PNP are the key enzymes of the purine salvage pathway. ADA converts deoxyadenosine to deoxyinosine, and adenosine to inosine, respectively. PNP converts guanosine and deoxyguanosine to guanine, inosine, and deoxyinosine to hypoxanthine. The accumulated dAdo in ADA deficiency inhibits SAH hydrolase, leading to accumulation of SAH, which inhibits transmethylation of various biomolecules. The effects of the inhibition or deficiency of RNR, SAMHD1, ADA, and PNP are also summarized. RNR: ribonucleotide reductase; SAMHD1: sterile alpha motif and histidine-aspartic acid domain-containing protein 1; dNTP: deoxynucleoside triphosphate; NDP: nucleoside diphosphate; dNDP: deoxynucleoside diphosphate; dNMP: deoxynucleoside monophosphate; dATP: deoxyadenosine triphosphate; dGTP: deoxyguanosine triphosphate; dNs: deoxyribonucleosides; PPP: triphosphate; ADA: adenosine deaminase; PNP: purine nucleoside phosphorylase; Ado: adenosine; dAdo: deoxyadenosine; Ino: Inosine; dIno: deoxyinosine; dGua: deoxyguanosine; SAM: S-adenosyl methionine; SAH: S-adenosyl homocysteine; SAHH: SAH hydrolase; Hyc: homocysteine; Met: methionine; X: a biomolecule; and X-CH3: a methylated biomolecule.

Another protein, which has been shown to be critical for regulating the dNTP pool in mammalian cells, is the sterile alpha motif and histidine-aspartic acid domain-containing protein 1 (SAMHD1), a dNTP triphosphohydrolase that hydrolyzes nucleotide triphosphate 
into triphosphate and a nucleoside (Figure 1) [21,22]. SAMHD1 mediated degradation of dNTPs plays an essential role in maintaining low levels of dNTP pools outside the $S$ phase of the cell cycle. In fact, SAMHD1 but not RNR is the principal regulator of dNTP levels in mammalian cells, as indicated by the dramatic accumulation of dNTP pools in SAMHD1 depleted cells [23-25]. SAMHD1 expression restricts viral infection by depleting cellular dNTPs, which are essential for viral reverse transcription and replication [26-29]. SAMHD1 mutations are associated with Aicardi-Goutières syndrome (AGS), a congenital neurodegenerative autoimmune disorder. In addition, SAMHD1 is frequently mutated in chronic lymphocytic leukemia (CLL) and colorectal cancers [30,31]. SAMHD1 was recently shown to play dNTPase-dependent and dNTPase-independent functions in DSB repair by NHEJ and homologous recombination, respectively [32-34]. Although SAMHD1 was proposed to possess a nuclease activity $[35,36]$, subsequent studies showed that the nuclease activity of SAMHD1 was due to contaminants present in the SAMHD1 preparations [37-39]. Structurally, SAMDH1 possesses an N-terminal SAM domain, followed by a catalytic HD domain and a short C-terminal end. It has been shown that dGTP acts as a substrate as well as an allosteric activator of SAMDH1. SAMDH1 is also stimulated by GTP, a nucleotide that exists in higher amounts than dGTP in most cells [40].

\section{Cellular Nucleotide Pool and V(D)J Recombination}

The $\mathrm{V}(\mathrm{D}) \mathrm{J}$ recombination, which joins $\mathrm{V}_{\mathrm{H}}, \mathrm{D}_{\mathrm{H}}$, and $\mathrm{J}_{\mathrm{H}}$ gene segments on the heavy chain, and $\mathrm{V}_{\mathrm{L}}$ and $\mathrm{J}_{\mathrm{L}}$ gene segments on the light chain, is a complex and intricate process that produces the DNA segments encoding $V$ regions of immunoglobulins [1]. The V(D)J recombination is initiated by the products of recombination activating genes (RAG1/RAG2), which are expressed in developing lymphocytes, where they induce DSBs at conserved recombination signal sequences (RSS) [41-43]. Upon identifying and interacting with RSS, the RAG cuts these signal sequences and releases V, D, and J gene segments [44-47]. The RSS consists of a highly conserved heptameric sequence and nonameric sequences separated by poorly conserved 12-23 base pair (bp)-long spacer sequences [44]. While the heptameric sequence plays an essential role as a recognition element, the nonameric sequence is dispensable for recombination [48]. The length of the spacers at the RSS sequences at the $3^{\prime}$ end of the $V_{\mathrm{H}}$ segment and the $5^{\prime}$ end of the $\mathrm{J}_{\mathrm{H}}$ is $23 \mathrm{bp}$, whereas the $\mathrm{D}_{\mathrm{H}}$ fragment contains $12 \mathrm{bp}$ long spacer at both the $5^{\prime}$ and $3^{\prime}$ RSS. The $12 / 23$ rule ensures that efficient recombination takes place between RSS with different spacer lengths, ensuring the joining of $\mathrm{D}_{\mathrm{H}}$ with $\mathrm{J}_{\mathrm{H}}$ and $\mathrm{V}_{\mathrm{H}}$, and preventing the joining of $\mathrm{V}_{\mathrm{H}}$ with $\mathrm{J}_{\mathrm{H}}[49,50]$.

The V(D)J recombinase comprises two lymphoid-specific proteins, RAG1 and RAG2, which function with non-lymphoid-specific DNA bending or twisting factors HMG1A and HMG1B to induce DNA cleavage [42,51]. The RAG complex binds to RSS sequences that need to be recombined and creates nicks at the junction between the coding segment and the RSS to form a nicked paired complex [52,53]. The free 3'-hydroxyl groups produced as a result of nicking then initiate transesterification reactions on the phosphorous atoms in opposite DNA strands, resulting in the development of hairpins on the coding gene segments and blunt ends on the signal sequence end. The second phase of recombination involves numerous non-homologous end-joining DNA factors that assist in joining the coding DNA ends and is characterized by the loss or addition of extra nucleotides at the junctions, thus contributing to junctional diversity [54]. An Artemis endonuclease unwraps the hairpin produced by the cleavage of RAG protein. The off-center nicking of hairpins results in the formation of short palindromic sequences called P-nucleotides [55]. In addition to P-nucleotides, junctional diversity also results from the random addition of a small number of N-nucleotides by terminal deoxynucleotidyl transferase (TdT) [45,56].

The TdT belongs to $X$ family polymerases that can incorporate nucleotides at the 3 '-end of DNA irrespective of DNA templates $[45,56]$. The presence of GC-rich nucleotides in the $\mathrm{N}$ region sequences of Ig genes suggests a preference of TdT for dGTP and dCTP. Studies on the inherited diseases resulting from deficiencies of enzymes involved in nucleotide metabolism highlight the importance of nucleotide pool imbalance in $\mathrm{V}(\mathrm{D}) \mathrm{J}$ recombination. 
Deficiencies in adenosine deaminase (ADA) and purine nucleoside phosphorylase (PNP) result in dNTP pool imbalances that affect lymphocyte development [57]. ADA, an essential enzyme of the purine salvage pathways, converts deoxyadenosine to deoxyinosine and adenosine to inosine (Figure 1). The deficiency in ADA leads to severe depletion of Tand B-lymphocytes and impaired cellular and humoral immunity and dysregulation, such as severe combined immunodeficiency disease. The severe immune deficiency caused by ADA deficiency is due to the accumulation and downstream effects of adenosine, deoxyadenosine, and dATP. Accumulated dATP also leads to the depletion of other dNTPs by feedback inhibition of RNR, resulting in impaired DNA synthesis, replication, and repair. As ADA is highly expressed in lymphoid tissues, particularly the thymus, ADA deficiency severely affects thymocyte distribution and development [58]. However, exactly which stage of thymocyte development and differentiation is affected by ADA deficiency remains largely unknown. Although, unlike T-lymphocytes, early B-lymphocyte development is not disturbed by ADA deficiency, it affects B-lymphocyte distribution with severe B-cell lymphopenia and hypoglobulinaemia. As the formation of the germinal centers is severely affected in ADA deficiency, antigen-dependent development of B cells and B-cell memory generation is likely affected [59]. ADA-deficient mice showed the reduced proliferative ability of B lymphocytes and accumulated IgM antibodies with concomitant decrements in $\operatorname{IgG}$.

Nucleotide pool imbalance due to ADA deficiency or supplementation of 2-deoxyadenosine in lymphoid cell lines transfected with $\mathrm{V}(\mathrm{D}) \mathrm{J}$ recombination substrates severely decreased V(D)J recombination frequency (Figure 2). Analysis of the recombination junctions revealed an increase in the insertions of A-T nucleotides at the coding joints, resulting in a two- to fourfold decrease in the ratio of $\mathrm{G}+\mathrm{C} / \mathrm{A}+\mathrm{T}$ in the $\mathrm{N}$ regions [60]. Consistently, analysis of the N-region nucleotide compositions of $\mathrm{V}_{\mathrm{H}}-\mathrm{D}_{\mathrm{H}}-\mathrm{J}_{\mathrm{H}}$ regions of Ig- $\mu$ heavy chains B-cells from ADA patients revealed an increase in A-T content, resulting in a $\sim$ threefold decrease in $\mathrm{G}+\mathrm{C} / \mathrm{A}+\mathrm{T}$ ratios [60]. In addition, accumulated deoxyadenosine irreversibly inactivates S-adenosyl-L-homocysteine (SAH) hydrolase, leading to accumulation of SAH and inhibition of transmethylation, which is necessary for lymphocyte development (Figure 1) [61,62]. Because of the high proliferation rate of lymphocytes, ADA is highly expressed in lymphocytes, a possible reason for severe lymphotoxic effects of ADA deficiency.

PNP degrades guanosine and deoxyguanosine to guanine, and inosine and deoxyinosine to hypoxanthine. Like ADA, the deficiency of PNP results in the accumulation of deoxyguanosine, which gets phosphorylated to dGTP, thus resulting in its accumulation (Figure 1). Like the accumulation of dATP in ADA deficiency, the accumulated dGTP also exerts lymphotoxic effects with profound T-cell abnormalities and variable B-cell function [63,64]. The exposure of lymphoid cell lines transfected with V(D)J recombination substrates to deoxyguanosine does not affect the $\mathrm{G}-\mathrm{C}$ content of $\mathrm{N}$ regions but leads to a fourfold decrease in the recombination of coding joints [60]. Although defects in the B-cell development in PNP deficiency are yet to be fully understood and are primarily attributed to T-cell abnormalities, PNP deficiency also has direct, T-cell independent effects on B-cell immunity [65]. The long-term exposure to hydroxyurea, an inhibitor of RNR, leads to an increase in illegitimate T-cell VDJ-recombination, suggesting that a deviation from optimal dNTP pool balance interferes with V(D)J recombination [66]. As SAMHD1 depletion leads to dramatic accumulation of both dATP and dGTP nucleotides, which interfere with SHM and CSR, it will be interesting to know if the B- and T-lymphocyte development and the process of $\mathrm{V}(\mathrm{D}) \mathrm{J}$ recombination is also affected by SAMHD1 depletion. 
A

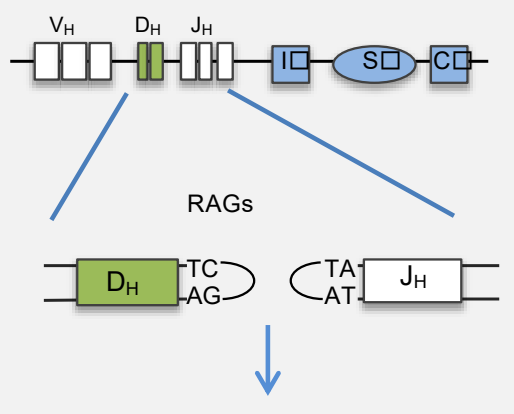

dNTP pool

Imbalance

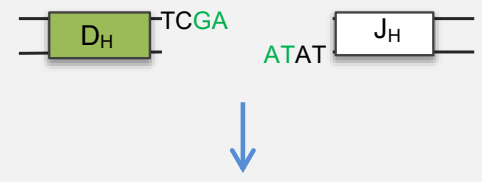

Altered TdT

activity and

end joining

Impaired V(D)」 recombination and lymphocyte development

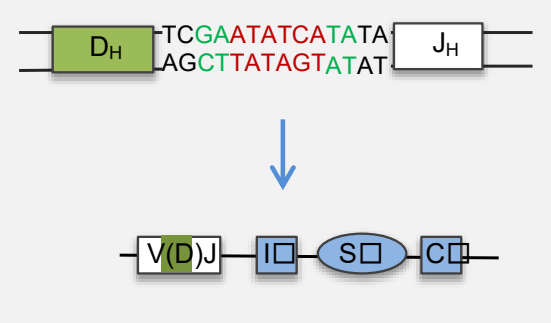

B
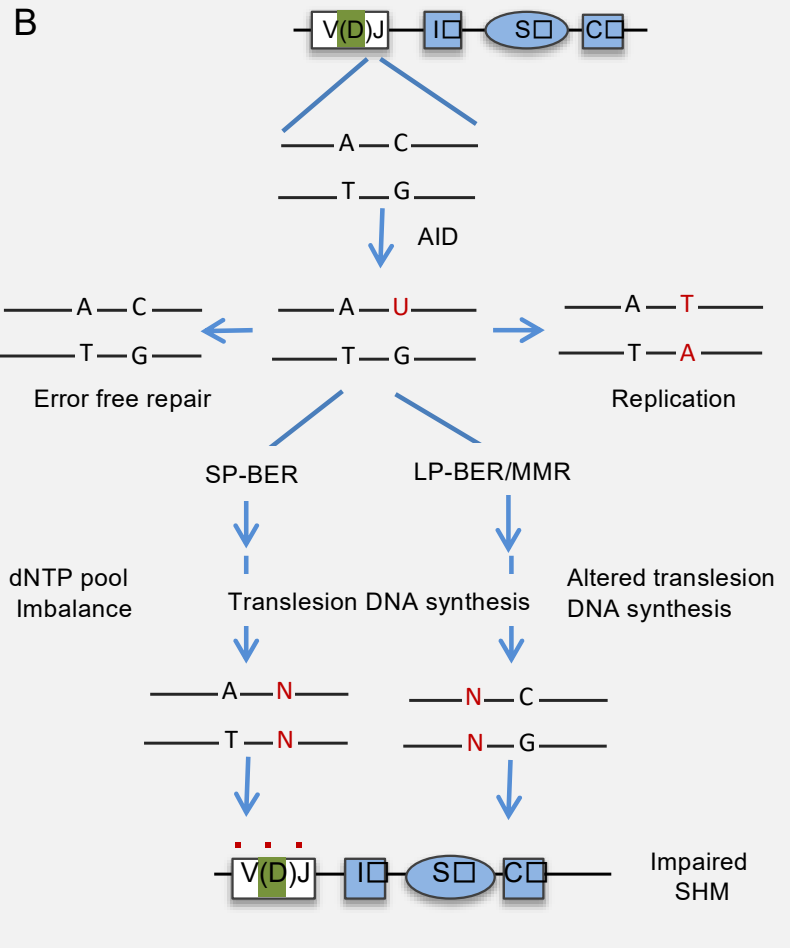

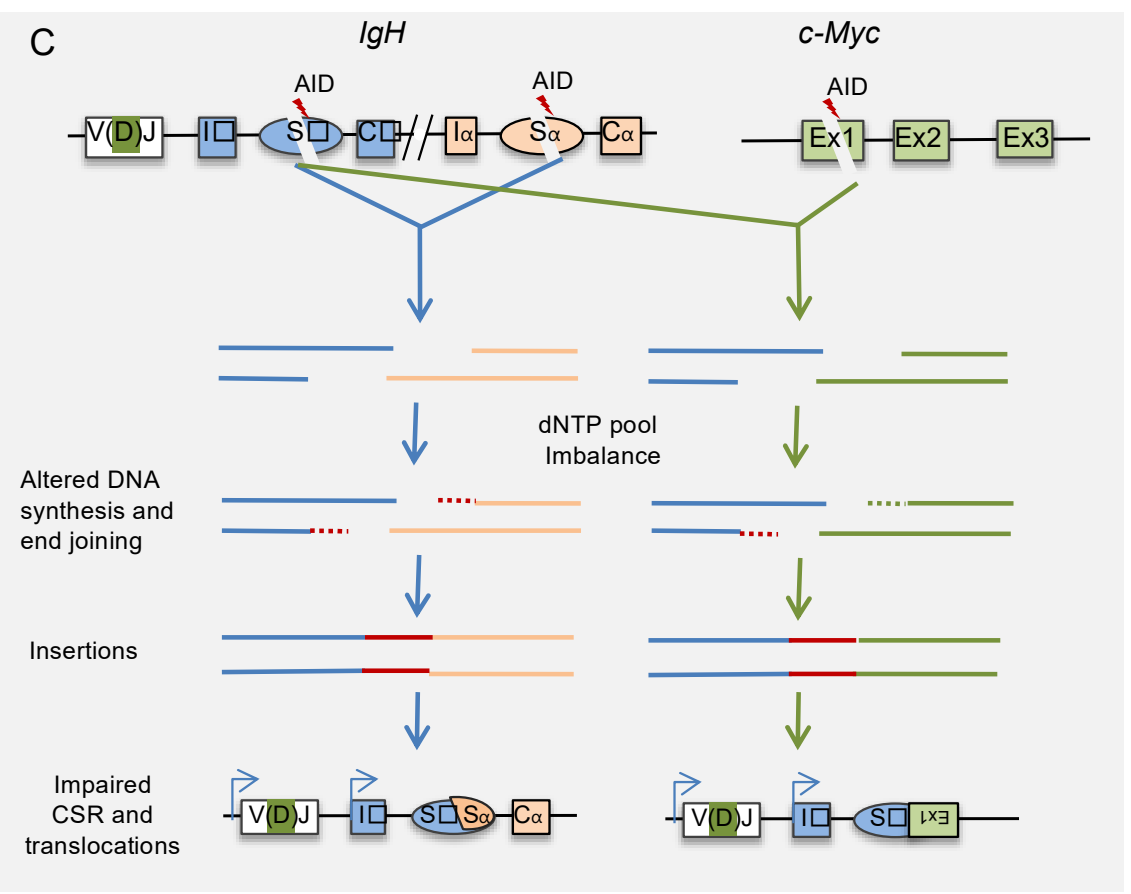

Figure 2. Effect of nucleotide pool imbalance on antibody gene diversification. (A) Imbalanced dNTP pool impairs the end-joining of RAG-induced DSBs by altering the activity of TdT, and possibly other DNA polymerases involved in end-joining during VDJ recombination. The red-colored nucleotides at the junction represent N-segment, and green-colored nucleotides represent P-segments. (B) The imbalance in the dNTP pool affects the translesion DNA polymerases involved in repairing mismatches produced by AID during hypermutation of recombined V region. (C) The dNTP pool imbalance also affects end-joining of AID-induced DSBs during physiological CSR and aberrant chromosomal translocations involving antibody genes. The imbalanced dNTP pool affects the activity of DNA polymerases and possibly other end-joining enzymes, leading to long insertions at the recombination junctions. AID: activation-induced cytidine deaminase; RAG: recombination activating genes; TdT: terminal deoxynucleotidyl transferase; SP-BER: short patch-base excision repair; LP-BER: long patch-base excision repair; MMR: mismatch repair. 


\section{Cellular Nucleotide Pool and Somatic Hypermutation}

An immunoglobulin is consists of a $\mathrm{V}$ region encoded by recombined $\mathrm{V}(\mathrm{D}) \mathrm{J}$ segments and a constant $(C)$ region encoded by one of the $C \mu, C \delta, C \alpha, C \varepsilon$, or $C \gamma$ genes. The constant regions of all Igs, except $C \delta$, are preceded by highly repetitive switch (S) regions [1]. Both antigen-independent $\mathrm{V}(\mathrm{D}) \mathrm{J}$ recombination during early B-cell differentiation and antigen-mediated SHM and CSR in mature B cells are essential for antibody maturation. SHM, the driving force for antibody affinity maturation, introduces non-templated point mutations at a rate of $10^{-2}-10^{-3}$ per base pair into the recombined variable regions $(\mathrm{V})$ of both heavy and light chain Ig genes, resulting in the dramatic increments in the affinity of antibodies after affinity maturation in the germinal center of secondary lymphoid organs. On the other hand, CSR replaces heavy chain constant region exons encoding for the IgM with a downstream constant region encoding another antibody isotype, enabling B-cells to produce antibodies with diverse effector functions while retaining their antigen specificities.

Although mechanistically different, both SHM and CSR are initiated by AID-induced cytosine deamination of transcription-exposed single-stranded DNA, resulting in the formation of $\mathrm{U} / \mathrm{G}$ mismatches and subsequent DNA cleavage in $\mathrm{V}$ or $\mathrm{S}$ regions, respectively $[5,67,68]$. While replication over $\mathrm{U} / \mathrm{G}$ mismatches prior to the excision of uracil results in the transition of $\mathrm{C}: \mathrm{G}$ to $\mathrm{T}: \mathrm{A}$, the vast majority of mutations during SHM are introduced by noncanonical G1 phase variants of base excision repair (BER) and mismatch repair (MMR) pathways, both of which employ error-prone DNA synthesis by translesion DNA polymerases [67,69-71]. While most U/G mismatches are faithfully repaired by canonical BER or MMR pathways, their error-prone repair by noncanonical BER or MMR pathways results in transition or transversion mutations at not only $\mathrm{C} / \mathrm{G}$ but also flanking A/T base pairs. The excision of uracils primarily by UNG, and to a lesser extent, by SMUG1, the key enzymes of the BER pathway, generate abasic sites [72,73]. The repair of abasic sites by short-patch BER pathway, employing translesion DNA polymerases REV1 and Poln, generates transition and transversion mutations at G:C base pairs [73-78]. Alternatively, a long DNA patch surrounding U/G mismatches or abasic sites can also be excised by noncanonical MMR or long-patch BER, respectively. The stranded DNA gap produced thereby is filled by translesion DNA polymerases, resulting in transition and transversion mutations at A:T base pairs [79]. EXO1 creates the excision patches following nicking of the $\mathrm{U} / \mathrm{G}$ mismatches or abasic sites by $\mathrm{MutL} \alpha$ complex or apurinic/apyrimidinic endonucleases, respectively [79-81].

Interestingly, AID-induced SHM occurs in the G1 phase of the cell cycle, where dNTP pool concentrations are lowest $[82,83]$. The restriction of SHM to G1 phase suggests that dNTP paucity may promote SHM and that the accumulation of dNTPs or their imbalance may interfere with the normal functions of DNA polymerases involved in SHM. Recently, inactivation of Samhd1 in mice carrying hen egg lysozyme (HEL) immunoglobulintransgene $\left(S W_{H E L}\right.$ mice) led to substantially increased levels of dNTPs in B cells [84]. Interestingly, this de-restriction of the dNTP pool in the G1 phase by the inactivation of Samhd1 in germinal center B cells affected SHM (Figure 2). Lack of SAMHD1 resulted in a significant increase in $\mathrm{C} / \mathrm{G}$ to $\mathrm{A} / \mathrm{T}$ transition mutations, whereas transversions at $\mathrm{A} / \mathrm{T}$ and C/G base pairs showed significant decreases. Similarly, an independent study also showed a decrease in the SHM frequency in the $\mathrm{S} \mu$ region of primary spleen cells derived from Samhd1 KO mice [33]. These results suggest that SAMHD1-induced dNTP paucity contributes to AID-induced mutagenesis. Although, like Samhd1 inactivation, Msh2 knockout decreases A/T mutations and C/G transversions, the perturbation of SHM upon Samhd1 inactivation was unlikely due to the inhibition of MMR. It is because Samhd1 inactivation neither focuses on AID-induced mutation on AGCW hotspots nor shows strand bias, the signatures of MMR inactivation [85]. Similarly, it was also demonstrated that accumulation of dNTPs upon SAMHD1 inactivation does not alter the rate of uracil excision by inhibiting UNG activity [84]. The hypermutation phenotypes of Samhd1 inactivated B cells show similarity with $\mathrm{PCNA}^{-/-}$and $\mathrm{POLH}^{-/-} \mathrm{B}$ cells. This observation suggests that the deficiency of SAMHD1 may reduce PCNA ubiquitination and Poln recruitment to V region of Ig with- 
out affecting the excision uracils. However, it remains to be analyzed whether dNTP pool imbalance caused by SAMHD1 deficiency impairs somatic hypermutation by affecting the recruitment of translesion DNA polymerases or modulating their activities. As SAMHD1 localizes to immunoglobulin genes in mouse B cell line, it would be interesting to analyze if it is implicated in the local depletion of dNTP pools to promote optimal SHM [33].

\section{Cellular Nucleotide Pool and Class Switch Recombination}

Generation of comprehensive humoral immune response requires high affinity and specific antibodies and the production of different antibody isotypes through CSR. The process of CSR changes the class or isotype of Ig expressed by B cells from IgM to other isotypes such as IgA, IgG, or IgE. Like SHM, AID-induced DNA breaks in Ig intronic switch (S) regions, positioned upstream of each of the constant regions of Ig isotype genes, initiates CSR $[5,68]$. CSR involves cleavage and joining of universal donor $S \mu$ and one of the downstream acceptor $S$ regions, which changes the constant region portion of the antibody heavy chain without affecting the variable region, and thus the antibody specificity remains unchanged (Figure 2). In CSR, the AID-induced SSBs in S regions are converted into DSBs, followed by the recombination of the two cleaved $S$ regions by the action of classical nonhomologous end-joining (c-NHEJ) or alternative end-joining (alt-EJ) pathways $[67,69,86]$. The joining of the cleaved $\mathrm{S}$ regions by c-NHEJ requires little or no sequence homology between cleaved $S$ region DNA ends, whereas alt-EJ utilizes the microhomology $(\mathrm{MH})$ between the single-stranded overhangs of the cleaved S region DNA ends. Usually, AIDinduced DNA breaks are restricted to V or S regions of the Ig genes; however, uncontrolled expression or mistargeting of AID to non-Ig loci induces mutations and chromosomal translocations in both B lymphocytes as well as non-lymphocytic cells. The frequently observed chromosomal translocations between Ig locus and proto-oncogenes such as c-MYC, FGFR, BCL-6, or BCL-2 are the hallmarks of B-cell malignancies [87-90].

In an attempt to identify proteins that function at AID-induced DNA-break sites in one of the $S$ regions of the mouse Ig locus, a recent study applied locus-specific insertional chromatin immunoprecipitation and identified SAMHD1 as a novel regulator of CSR $[33,91]$. Dramatic accumulation of dNTPs, particularly purines, was observed in SAMHD1 depleted mouse B cell line CH12F3-2A and spleen B cells derived from Samhd1 KO mice. The accumulation of dNTPs impaired not only AID-induced CSR but also aberrant chromosomal translocations between IgH and c-Myc loci (Figure 2). Site-directed mutational analysis of SAMHD1 further revealed that the effects of SAMHD1 depletion on $\mathrm{CSR}$ and IgH/c-Myc translocations were dependent on its dNTPase activity. The defects in $\mathrm{CSR}$ and $\mathrm{IgH} / \mathrm{cMyc}$ translocations were not due to impaired AID-induced DNA breaks or synapsis between the two S-regions. The analysis of the CSR and IgH/cMyc breakpoint junctions revealed that a high frequency of longer nucleotide insertions is a notable feature in SAMHD1 deficiency, indicating that accumulation of nucleotides affects the end-joining step of DSBs (Figure 2).

Interestingly, CSR mediated by CRISPR/Cas9-induced staggered but not blunt DSBs is impaired by SAMHD1 depletion. It is essential to mention that most DNA breaks by AID are staggered, that require efficient end-processing prior to their joining by c-NHEJ or alt-EJ pathways [92]. Consistently, the supplementation of purine nucleosides into the culture medium severely affected both CSR and Igh/cMyc translocations. These results suggest that the intracellular dNTP concentration is an important regulator of antibody diversity and genomic instability. Multiple mechanisms, including altered activities of DNA polymerases and dNTP sensitive DNA end-processing enzymes at DSBs may be affected by imbalanced dNTP pool, resulting in the impaired CSR and chromosomal translocations. Consistently, the overexpression of TdT in Samhd1 KO but not in WT CH12F3-2A B cell line reduced the frequency of CSR and increased the insertional events at CSR junctions. Since mature B cells do not express TdT, it can be envisaged that SAMHD1 inactivation would affect the TdT activity and V(D)J recombination. Both V(D)J recombination and CSR rely on NHEJ mediated repair pathways, where the dNTP pool 
plays a critical role. Similar to the defects in CSR and IgH/cMyc translocations, the elevated dNTP pools showed significant increases in both the frequency and length of insertions at the CRISPR/Cas9-induced translocation junctions and the repair of plasmid-based artificial DNA repair substrates [32,33]. These data strongly suggest a role of the dNTP pool in regulating cellular processes that depend on NHEJ. As SAMHD1 also localizes to DNA break sites $[30,33,34]$, the possible role of SAMHD1 in local depletion of dNTP pool in DSB repair by non-homologous end-joining remains to be analyzed. Interestingly, SAMHD1 has also been reported to promote homologous recombination through its ability to interact with and recruit C-terminal binding protein interacting protein (CtIP) at the DSB site [34]. Therefore, it is yet to be analyzed whether SAMHD1 deficiency perturbs antibody generation in chicken B cells, which diversify Ig genes by a gene conversion that relies on homologous recombination [93].

\section{Conclusions}

Maintaining adequate levels and balance of dNTPs within the permissible physiological range is an important determinant of the accuracy and activity of DNA polymerases, which are involved not only in genomic DNA replication but also in DNA repair and recombination. The ability of the dNTP pool imbalance to modulate the rate and fidelity of DNA synthesis is strongly associated with the ability of the cell to protect against genomic instability induced by various environmental factors and physiological processes. The objective of this review was to discuss how dNTP pool balance affects the three critical processes involved in antibody gene diversification, namely V(D)J recombination, SHM, and CSR. While V(D)J recombination and CSR involve joining of RAG- or AID-induced DNA double-strand breaks, respectively, by NHEJ pathway proteins, SHM relies on BER and MMR of AID-induced uracils to introduce mutations into the recombined V region. In mammalian cells, the activity of NHEJ is maximum during the G1 phase of the cell cycle, where dNTP concentrations are lowest due to low RNR and high SAMHD1 activities. Interestingly, all three antibody diversification processes are predominantly restricted to the G1 phase of the cell cycle, indicating that antibody gene diversification has evolved to function at low concentrations of the dNTP pool $[82,83,94]$ (Figure 2). Therefore, it is not surprising that the accumulation and imbalance of dNTPs interfere with antibody gene diversification processes.

The dNTPs are synthesized by RNR in the cytoplasm and diffused to the nucleus for DNA synthesis [95]. However, a number of reports showed that RNR is also localized to the sites of DNA breaks [96-99]. In contrast to RNR, SAMHD1 is mainly localized to the nucleus, which may be helpful in the robust depletion of the nuclear dNTP pool outside the S-phase of the cell cycle. Like RNR, SAMHD1 was found associated with chromatin at DNA break repair sites $[33,34]$. These findings suggest that the repair of DNA breaks may require local adjustment of dNTP concentrations for efficient DNA end-joining. However, the analysis of the local variations in the dNTP pool would require the development of advanced probes to measure local dNTP concentrations accurately.

The accumulation of purine nucleotides affects lymphocyte development at the stage of V(D)J recombination and causes severe immunodeficiencies [57]. Similarly, the accumulation of purine nucleotides caused by SAMHD1 deficiency impairs both SHM and CSR in mice and B-cell lines $[33,84]$. The purine nucleotides are also accumulated in Aicardi-Goutières syndrome with germline SAMHD1 mutations. However, the effect of SAMHD1 inactivating mutations on immune system diversification in patients with Aicardi-Goutières syndrome is yet to be analyzed. The imbalance in the dNTP pool affects $\mathrm{V}(\mathrm{D}) \mathrm{J}$ recombination and CSR by interfering with the end joining, whereas SHM is affected due to impaired translesion DNA synthesis. Although transition mutations are the most frequent mutations in our genome, they are less mutagenic than transversion mutations. The restriction of dNTPs by SAMHD1 promote transversion mutations during SHM, thereby affecting the binding characteristics of the antibodies. Therefore, it is conceivable to believe that patients with SAMHD1 inactivating mutations may be compromised in producing 
effective immune response. The imbalanced dNTP pool is known to increase the formation of mismatches and affect the accuracy of MMR [100]. For example, the accumulation of dNTPs in colon cancers with heterozygous SAMHD1 mutations exacerbate MMR mutation phenotypes [31]. Template-dependent DNA polymerases $m u(\mu)$ and lambda $(\lambda)$ and template-independent TdT play non-overlapping roles in junctional processing during $\mathrm{V}(\mathrm{D}) \mathrm{J}$ recombination. Thus, imbalance in the dNTP pool may affect V(D)J recombination by modulating the activities of not only TdT but also polymerase $\mu$ and $\lambda$ [101].

The accumulation of purine dNTPs leads to increased frequency of insertions at recombination junctions that are inhibitory for CSR and $\mathrm{IgH} / \mathrm{c}-\mathrm{Myc}$ translocations, suggesting that dNTP pool restriction favors DNA repair by NHEJ. Recent studies indicate that DNA polymerase theta (POLQ) is responsible for nucleotide insertions during NHEJ [102-104]. Interestingly, deficiency in POLQ leads to decreased insertions at the CSR junctions and increased frequency of IgH/c-Myc translocations [103]. These findings suggest that dNTP pool imbalance may modulate the activity of DNA polymerases involved in the end-joining. In fact, the accumulation of purine nucleotides leads to increased insertional events and reduced CSR activity in B-cell lines overexpressing TdT. An elevated dNTP pool may also affect end-resection during the end-joining of the DNA breaks. In addition, dNTP pool imbalance may also affect other dNTP-sensitive enzymes such as DNA/RNA helicases [105-107]. Long templated insertions have also been observed between the V and DJ segments in the human Ig locus and are associated with the development of effective antibodies [108]. Together, these findings suggest that dNTP imbalance can modulate the activities of DNA repair enzymes involved in antibody gene diversification.

\section{Future Directions}

Extrapolating from the defects observed in lymphocyte development and V(D)J recombination in patients with ADA and PNP deficiencies, it is conceivable that the dNTP pool imbalance caused by deficiencies of other enzymes of nucleotide metabolism may also affect $\mathrm{V}(\mathrm{D}) \mathrm{J}$ recombination. For instance, SAMHD1 could be playing an important role in maintaining the dNTP pool balance for optimal V(D)J recombination. Therefore, it is important to study if the restriction of the dNTP pool by SAMHD 1 during B-cell development affects the frequency and junctional diversity in V(D)J recombination. Similarly, it would also be important to study if ADA and PNP are required for AID-induced physiological and aberrant recombination. More importantly, further studies are also required to identify DNA polymerases primarily affected by dNTP pool imbalance caused by ADA, PNP, and SAMHD1 inactivation during V(D)J recombination, CSR, SHM, and the genomic instability associated with these processes. In case of ADA deficiency, modulation of the activity of $\mathrm{TdT}$ is likely responsible for the defects in V(D)J recombination. However, it remains to be analyzed if the imbalance in the dNTP pool also affects the activities of polymerase $\mu$ and $\lambda$ which are implicated in V(D)J recombination. Similarly, the DNA polymerases whose activities are affected by dNTP de-restriction upon SAMHD1 depletion during AID-induced CSR, SHM, and chromosomal translocations are yet to be identified.

Author Contributions: A.H., N.A.B. and A.A. conceptualized and designed the review article; A.A., A.H. and N.A.B. wrote the manuscript. All authors reviewed the manuscript and approved the final version.

Funding: Start-Up Research Grant (SRG-2020-000819) from the Department of Science and TechnologyScience and Engineering Research Board (DST-SERB).

Institutional Review Board Statement: Not applicable.

Informed Consent Statement: Not applicable.

Acknowledgments: The laboratory of AH is financially supported by the Start-Up Research Grant (SRG-2020-000819) from the Department of Science and Technology-Science and Engineering Research Board, Govt of India.

Conflicts of Interest: The authors declared that there are no competing financial interests. 


\section{References}

1. Murphy, K.M.; Weaver, C.; Mowat, A. Janeway's Immunobiology, 9th ed.; Garland Science: New York, NY, USA, 2017.

2. Leder, P. The genetics of antibody diversity. Sci. Am. 1982, 246, 102-115. [CrossRef]

3. Tonegawa, S. Somatic generation of antibody diversity. Nature 1983, 302, 575-581. [CrossRef]

4. Honjo, T. Immunoglobulin genes. Annu. Rev. Immunol. 1983, 1, 499-528. [CrossRef]

5. Muramatsu, M.; Kinoshita, K.; Fagarasan, S.; Yamada, S.; Shinkai, Y.; Honjo, T. Class switch recombination and hypermutation require activation-induced cytidine deaminase (AID), a potential RNA editing enzyme. Cell 2000, 102, 553-563. [CrossRef]

6. Nagaoka, H.; Muramatsu, M.; Yamamura, N.; Kinoshita, K.; Honjo, T. Activation-induced deaminase (AID)-directed hypermutation in the immunoglobulin $\mathrm{S} \mu$ region. J. Exp. Med. 2002, 195, 529-534. [CrossRef] [PubMed]

7. Tarlinton, D.; Good-Jacobson, K. Diversity among memory B cells: Origin, consequences, and utility. Science 2013, 341, $1205-1211$. [CrossRef] [PubMed]

8. Mathews, C.K. DNA precursor metabolism and genomic stability. FASEB J. 2006, 20, 1300-1314. [CrossRef] [PubMed]

9. Mathews, C.K. Deoxyribonucleotides as genetic and metabolic regulators. FASEB J. 2014, 28, 3832-3840. [CrossRef] [PubMed]

10. Mathews, C.K. Deoxyribonucleotide metabolism, mutagenesis and cancer. Nat. Rev. Cancer 2015, 15, 528-539. [CrossRef]

11. Kunz, B.A.; Kohalmi, S.E.; Kunkel, T.; Mathews, C.K.; McIntosh, E.M.; Reidy, J.A. Deoxyribonucleoside triphosphate levels: A critical factor in the maintenance of genetic stability. Mutat. Res. Genet. Toxicol. 1994, 318, 1-64. [CrossRef]

12. Meuth, M. The molecular basis of mutations induced by deoxyribonucleoside triphosphate pool imbalances in mammalian cells. Exp. Cell Res. 1989, 181, 305-316. [CrossRef]

13. Tubbs, A.; Nussenzweig, A. Endogenous DNA damage as a source of genomic instability in cancer. Cell 2017, 168, 644-656. [CrossRef]

14. Nordlund, P.; Reichard, P. Ribonucleotide reductases. Annu. Rev. Biochem. 2006, 75, 681-706. [CrossRef] [PubMed]

15. Chimploy, K.; Mathews, C.K. Mouse ribonucleotide reductase control. J. Biol. Chem. 2001, 276, 7093-7100. [CrossRef] [PubMed]

16. Fairman, J.W.; Wijerathna, S.R.; Ahmad, F.; Xu, H.; Nakano, R.; Jha, S.; Prendergast, J.; Welin, R.M.; Flodin, S.; Roos, A.; et al. Structural basis for allosteric regulation of human ribonucleotide reductase by nucleotide-induced oligomerization. Nat. Struct. Mol. Biol. 2011, 18, 316-322. [CrossRef]

17. Hofer, A.; Crona, M.; Logan, D.; Sjöberg, B.-M. DNA building blocks: Keeping control of manufacture. Crit. Rev. Biochem. Mol. Biol. 2011, 47, 50-63. [CrossRef] [PubMed]

18. Chabes, A.; Thelander, L. Controlled protein degradation regulates ribonucleotide reductase activity in proliferating mammalian cells during the normal cell cycle and in response to DNA damage and replication blocks. J. Biol. Chem. 2000, 275, 17747-17753. [CrossRef] [PubMed]

19. Engström, Y.; Rozell, B. Immunocytochemical evidence for the cytoplasmic localization and differential expression during the cell cycle of the M1 and M2 subunits of mammalian ribonucleotide reductase. EMBO J. 1988, 7, 1615-1620. [CrossRef]

20. Fasullo, M.; Endres, L. Nucleotide salvage deficiencies, DNA damage and neurodegeneration. Int. J. Mol. Sci. 2015, 16, 9431-9449. [CrossRef]

21. Powell, R.D.; Holland, P.J.; Hollis, T.; Perrino, F.W. Aicardi-Goutières syndrome gene and HIV-1 restriction factor SAMHD1 is a dGTP-regulated deoxynucleotide triphosphohydrolase. J. Biol. Chem. 2011, 286, 43596-43600. [CrossRef]

22. Goldstone, D.; Ennis-Adeniran, V.; Hedden, J.J.; Groom, H.C.T.; Rice, G.; Christodoulou, E.; Walker, P.A.; Kelly, G.; Haire, L.F.; Yap, M.W.; et al. HIV-1 restriction factor SAMHD1 is a deoxynucleoside triphosphate triphosphohydrolase. Nature 2011, 480, 379-382. [CrossRef] [PubMed]

23. Franzolin, E.; Pontarin, G.; Rampazzo, C.; Miazzi, C.; Ferraro, P.; Palumbo, E.; Reichard, P.; Bianchi, V. The deoxynucleotide triphosphohydrolase SAMHD1 is a major regulator of DNA precursor pools in mammalian cells. Proc. Natl. Acad. Sci. USA 2013, 110, 14272-14277. [CrossRef] [PubMed]

24. Behrendt, R.; Schumann, T.; Gerbaulet, A.; Nguyen, L.A.; Schubert, N.; Alexopoulou, D.; Berka, U.; Lienenklaus, S.; Peschke, K.; Gibbert, K.; et al. Mouse SAMHD1 has antiretroviral activity and suppresses a spontaneous cell-intrinsic antiviral response. Cell Rep. 2013, 4, 689-696. [CrossRef]

25. Rehwinkel, J.; Maelfait, J.; Bridgeman, A.; Rigby, R.; Hayward, B.; Liberatore, R.; Bieniasz, P.D.; Towers, G.; Moita, L.; Crow, Y.; et al. SAMHD1-dependent retroviral control and escape in mice. EMBO J. 2013, 32, 2454-2462. [CrossRef] [PubMed]

26. Baldauf, H.-M.; Pan, X.; Erikson, E.; Schmidt, S.; Daddacha, W.; Burggraf, M.; Schenkova, K.; Ambiel, I.; Wabnitz, G.H.; Gramberg, T.; et al. SAMHD1 restricts HIV-1 infection in resting CD4+ T cells. Nat. Med. 2012, 18, 1682-1688. [CrossRef]

27. Hrecka, K.; Hao, C.; Gierszewska, M.; Swanson, S.K.; Kesik-Brodacka, M.; Srivastava, S.; Florens, L.; Washburn, M.; Skowronski, J. Vpx relieves inhibition of HIV-1 infection of macrophages mediated by the SAMHD1 protein. Nature 2011, 474, 658-661. [CrossRef] [PubMed]

28. Laguette, N.; Sobhian, B.; Casartelli, N.; Ringeard, M.; Chable-Bessia, C.; Ségéral, E.; Yatim, A.; Emiliani, S.; Schwartz, O.; Benkirane, M. SAMHD1 is the dendritic- and myeloid-cell-specific HIV-1 restriction factor counteracted by Vpx. Nature 2011, 474, 654-657. [CrossRef]

29. Lahouassa, H.; Daddacha, W.; Hofmann, H.; Ayinde, D.; Logue, E.C.; Dragin, L.; Bloch, N.; Maudet, C.; Bertrand, M.; Gramberg, T.; et al. SAMHD1 restricts the replication of human immunodeficiency virus type 1 by depleting the intracellular pool of deoxynucleoside triphosphates. Nat. Immunol. 2012, 13, 223-228. [CrossRef] [PubMed] 
30. Clifford, R.; Louis, T.; Robbe, P.; Ackroyd, S.; Burns, A.; Timbs, A.T.; Colopy, G.W.; Dreau, H.; Sigaux, F.; Judde, J.G.; et al. SAMHD1 is mutated recurrently in chronic lymphocytic leukemia and is involved in response to DNA damage. Blood 2014, 123, 1021-1031. [CrossRef] [PubMed]

31. Rentoft, M.; Lindell, K.; Tran, P.; Chabes, A.L.; Buckland, R.J.; Watt, D.L.; Marjavaara, L.; Nilsson, A.K.; Melin, B.; Trygg, J.; et al. Heterozygous colon cancer-associated mutations of SAMHD1 have functional significance. Proc. Natl. Acad. Sci. USA 2016, 113, 4723-4728. [CrossRef]

32. Akimova, E.; Gassner, F.J.; Schubert, M.; Rebhandl, S.; Arzt, C.; Rauscher, S.; Tober, V.; Zaborsky, N.; Greil, R.; Geisberger, R. SAMHD1 restrains aberrant nucleotide insertions at repair junctions generated by DNA end joining. Nucleic Acids Res. 2021, 49, 2598-2608. [CrossRef]

33. Husain, A.; Xu, J.; Fujii, H.; Nakata, M.; Kobayashi, M.; Wang, J.; Rehwinkel, J.; Honjo, T.; A Begum, N. SAMHD 1-mediated dNTP degradation is required for efficient DNA repair during antibody class switch recombination. EMBO J. 2020, 39 , e102931. [CrossRef]

34. Daddacha, W.; Koyen, A.E.; Bastien, A.J.; Head, P.; Dhere, V.R.; Nabeta, G.N.; Connolly, E.C.; Werner, E.; Madden, M.; Daly, M.B.; et al. SAMHD1 promotes DNA end resection to facilitate DNA repair by homologous recombination. Cell Rep. 2017, 20, 1921-1935. [CrossRef] [PubMed]

35. Beloglazova, N.; Flick, R.; Tchigvintsev, A.; Brown, G.; Popovic, A.; Nocek, B.; Yakunin, A.F. Nuclease activity of the human SAMHD1 protein implicated in the Aicardi-Goutières syndrome and HIV-1 restriction. J. Biol. Chem. 2013, 288, 8101-8110. [CrossRef] [PubMed]

36. Ryoo, J.; Choi, J.; Oh, C.; Kim, S.; Seo, M.; Kim, S.-Y.; Seo, D.; Kim, J.; White, T.E.; Brandariz-Nuñez, A.; et al. The ribonuclease activity of SAMHD1 is required for HIV-1 restriction. Nat. Med. 2014, 20, 936-941. [CrossRef] [PubMed]

37. Antonucci, J.; Gelais, C.S.; De Silva, S.; Yount, J.; Tang, C.; Ji, X.; Shepard, C.; Xiong, Y.; Kim, B.; Wu, L. SAMHD1-mediated HIV-1 restriction in cells does not involve ribonuclease activity. Nat. Med. 2016, 22, 1072-1074. [CrossRef] [PubMed]

38. Seamon, K.J.; Bumpus, N.N.; Stivers, J.T. Single-stranded nucleic acids bind to the tetramer interface of samhd1 and prevent formation of the catalytic homotetramer. Biochemistry 2016, 55, 6087-6099. [CrossRef]

39. Welbourn, S.; Strebel, K. Low dNTP levels are necessary but may not be sufficient for lentiviral restriction by SAMHD1. Virology 2015, 488, 271-277. [CrossRef]

40. Amie, S.M.; Bambara, R.A.; Kim, B. GTP is the primary activator of the anti-HIV restriction factor SAMHD1. J. Biol. Chem. 2013, 288, 25001-25006. [CrossRef]

41. Chun, J.J.; Schatz, D.G.; Oettinger, M.A.; Jaenisch, R.; Baltimore, D. The recombination activating gene-1 (RAG-1) transcript is present in the murine central nervous system. Cell 1991, 64, 189-200. [CrossRef]

42. Oettinger, M.; Schatz, D.; Gorka, C.; Baltimore, D. RAG-1 and RAG-2, adjacent genes that synergistically activate V(D)J recombination. Science 1990, 248, 1517-1523. [CrossRef] [PubMed]

43. Schatz, D.G.; Oettinger, M.A.; Baltimore, D. The V(D)J recombination activating gene, RAG-1. Cell 1989, 59, 1035-1048. [CrossRef]

44. Jung, D.; Alt, F.W. Unraveling V(D)J recombination: Insights into gene regulation. Cell 2004, 116, 299-311. [CrossRef]

45. Motea, E.A.; Berdis, A.J. Terminal deoxynucleotidyl transferase: The story of a misguided DNA polymerase. Biochim. Biophys. Acta 2010, 1804, 1151-1166. [CrossRef]

46. Sadofsky, M.J. The RAG proteins in V(D)J recombination: More than just a nuclease. Nucleic Acids Res. 2001, $29,1399-1409$. [CrossRef]

47. Schatz, D.G.; Ji, Y. Recombination centres and the orchestration of V(D)J recombination. Nat. Rev. Immunol. 2011, 11, 251-263. [CrossRef] [PubMed]

48. Ramsden, D.; Baetz, K.; Wu, G.E. Conservation of sequence in recombination signal sequence spacers. Nucleic Acids Res. 1994, 22, 1785-1796. [CrossRef] [PubMed]

49. van Gent, D.C.; Ramsden, D.; Gellert, M. The RAG1 and RAG2 proteins establish the 12/23 rule in V(D)J recombination. Cell 1996, 85, 107-113. [CrossRef]

50. Hiom, K.; Gellert, M. Assembly of a 12/23 paired signal complex: A critical control point in V(D)J recombination. Mol. Cell 1998, 1, 1011-1019. [CrossRef]

51. Van Gent, D.C.; Hiom, K.; Paull, T.T.; Gellert, M. Stimulation of V(D)J cleavage by high mobility group proteins. EMBO J. 1997, 16, 2665-2670. [CrossRef]

52. Agrawal, A.; Schatz, D.G. RAG1 and RAG2 form a stable postcleavage synaptic complex with DNA containing signal ends in V(D)J recombination. Cell 1997, 89, 43-53. [CrossRef]

53. Fugmann, S.D.; Lee, A.I.; Shockett, P.E.; Villey, I.J.; Schatz, D.G. The RAG proteins and V(D)J recombination: Complexes, ends, and transposition. Annu. Rev. Immunol. 2000, 18, 495-527. [CrossRef]

54. Malu, S.; Malshetty, V.; Francis, D.; Cortes, P. Role of non-homologous end joining in V(D)J recombination. Immunol. Res. 2012, 54, 233-246. [CrossRef]

55. Lu, H.; Schwarz, K.; Lieber, M.R. Extent to which hairpin opening by the Artemis: DNA-PKcs complex can contribute to junctional diversity in V(D)J recombination. Nucleic Acids Res. 2007, 35, 6917-6923. [CrossRef] [PubMed]

56. Benedict, C.L.; Gilfillan, S.; Thai, T.H.; Kearney, J.F. Terminal deoxynucleotidyl transferase and repertoire development. Immunol. Rev. 2000, 175, 150-157. [CrossRef] 
57. Edwards, N.L. Immunodeficiencies associated with errors in purine metabolism. Med. Clin. North. Am. 1985, 69, 505-518. [CrossRef]

58. Apasov, S.G.; Blackburn, M.R.; Kellems, R.E.; Smith, P.T.; Sitkovsky, M.V. Adenosine deaminase deficiency increases thymic apoptosis and causes defective T cell receptor signaling. J. Clin. Investig. 2001, 108, 131-141. [CrossRef]

59. Aldrich, M.B.; Chen, W.; Blackburn, M.R.; Martinez-Valdez, H.; Datta, S.K.; Kellems, R.E. Impaired germinal center maturation in adenosine deaminase deficiency. J. Immunol. 2003, 171, 5562-5570. [CrossRef]

60. Gangi-Peterson, L.; Sorscher, D.H.; Reynolds, J.W.; Kepler, T.B.; Mitchell, B.S. Nucleotide pool imbalance and adenosine deaminase deficiency induce alterations of N-region insertions during V(D)J recombination. J. Clin. Investig. 1999, 103, 833-841. [CrossRef]

61. Benveniste, P.; Zhu, W.; Cohen, A. Interference with thymocyte differentiation by an inhibitor of S-adenosylhomocysteine hydrolase. J. Immunol. 1995, 155, 536-544. [PubMed]

62. Hershfield, M.S.; Kredich, N.M.; Ownby, D.R.; Ownby, H.; Buckley, R. In vivo inactivation of erythrocyte S-adenosylhomocysteine hydrolase by 2'-deoxyadenosine in adenosine deaminase-deficient patients. J. Clin. Investig. 1979, 63, 807-811. [CrossRef] [PubMed]

63. Cohen, A.; Gudas, L.J.; Ammann, A.J.; Staal, G.E.J.; Martin, D.W. Deoxyguanosine triphosphate as a possible toxic metabolite in the immunodeficiency associated with purine nucleoside phosphorylase deficiency. J. Clin. Investig. 1978, 61, 1405-1409. [CrossRef] [PubMed]

64. Chan, T.-S. Deoxyguanosine toxicity on lymphoid cells as a cause for immunosuppression in purine nucleoside phosphorylase deficiency. Cell 1978, 14, 523-530. [CrossRef]

65. Somech, R.; Lev, A.; Simon, A.J.; Hanna, S.; Etzioni, A. T and B-cell defects in a novel purine nucleoside phosphorylase mutation. J. Allergy Clin. Immunol. 2012, 130, 539-542. [CrossRef] [PubMed]

66. Hanft, V.N.; Fruchtman, S.R.; Pickens, C.V.; Rosse, W.F.; Howard, T.A.; Ware, R.E. Acquired DNA mutations associated with in vivo hydroxyurea exposure. Blood 2000, 95, 3589-3593. [CrossRef]

67. Feng, Y.; Seija, N.; Di Noia, J.M.; Martin, A. AID in antibody diversification: There and back again. Trends Immunol. 2020, 41, 586-600. [CrossRef]

68. Revy, P.; Muto, T.; Levy, Y.; Geissmann, F.; Plebani, A.; Sanal, O.; Catalan, N.; Forveille, M.; Dufourcq-Lagelouse, R.; Gennery, A.; et al. Activation-induced cytidine deaminase (AID) deficiency causes the autosomal recessive form of the hyper-IgM syndrome (HIGM2). Cell 2000, 102, 565-575. [CrossRef]

69. Methot, S.; Di Noia, J. Molecular mechanisms of somatic hypermutation and class switch recombination. Adv. Immunol. 2017, 133, 37-87. [CrossRef]

70. Di Noia, J.; Neuberger, M.S. Altering the pathway of immunoglobulin hypermutation by inhibiting uracil-DNA glycosylase. Nature 2002, 419, 43-48. [CrossRef] [PubMed]

71. Rada, C.; Ehrenstein, M.; Neuberger, M.S.; Milstein, C. Hot spot focusing of somatic hypermutation in MSH2-deficient mice suggests two stages of mutational targeting. Immunity 1998, 9, 135-141. [CrossRef]

72. Dingler, F.A.; Kemmerich, K.; Neuberger, M.S.; Rada, C. Uracil excision by endogenous SMUG 1 glycosylase promotes efficient I g class switching and impacts on A: T substitutions during somatic mutation. Eur. J. Immunol. 2014, 44, 1925-1935. [CrossRef] [PubMed]

73. Rada, C.; Williams, G.T.; Nilsen, H.; Barnes, D.; Lindahl, T.; Neuberger, M.S. Immunoglobulin isotype switching is inhibited and somatic hypermutation perturbed in UNG-deficient mice. Curr. Biol. 2002, 12, 1748-1755. [CrossRef]

74. Weill, J.-C.; Reynaud, C.-A. DNA polymerases in adaptive immunity. Nat. Rev. Immunol. 2008, 8, 302-312. [CrossRef]

75. Delbos, F.; Aoufouchi, S.; Faili, A.; Weill, J.-C.; Reynaud, C.-A. DNA polymerase $\eta$ is the sole contributor of A/T modifications during immunoglobulin gene hypermutation in the mouse. J. Exp. Med. 2006, 204, 17-23. [CrossRef] [PubMed]

76. Zeng, X.; Winter, D.B.; Kasmer, C.; Kraemer, K.; Lehmann, A.R.; Gearhart, P.J. DNA polymerase $\eta$ is an A-T mutator in somatic hypermutation of immunoglobulin variable genes. Nat. Immunol. 2001, 2, 537-541. [CrossRef] [PubMed]

77. Kano, C.; Hanaoka, F.; Wang, J.-Y. Analysis of mice deficient in both REV1 catalytic activity and POLH reveals an unexpected role for POLH in the generation of $C$ to $G$ and $G$ to $C$ transversions during Ig gene hypermutation. Int. Immunol. 2012, 24, 169-174. [CrossRef]

78. Krijger, P.H.; Tsaalbi-Shtylik, A.; Wit, N.; Berk, P.C.M.V.D.; de Wind, N.; Jacobs, H. Rev1 is essential in generating G to C transversions downstream of the Ung2 pathway but not the Msh2+Ung2 hybrid pathway. Eur. J. Immunol. 2013, 43, 2765-2770. [CrossRef]

79. Stavnezer, J.; Linehan, E.K.; Thompson, M.R.; Habboub, G.; Ucher, A.J.; Kadungure, T.; Tsuchimoto, D.; Nakabeppu, Y.; Schrader C.E. Differential expression of APE1 and APE2 in germinal centers promotes error-prone repair and A:T mutations during somatic hypermutation. Proc. Natl. Acad. Sci. USA 2014, 111, 9217-9222. [CrossRef]

80. Bardwell, P.; Woo, C.J.; Wei, K.; Li, Z.; Martin, A.; Sack, S.Z.; Parris, T.; Edelmann, W.; Scharff, M.D. Altered somatic hypermutation and reduced class-switch recombination in exonuclease 1-mutant mice. Nat. Immunol. 2004, 5, 224-229. [CrossRef]

81. Zubani, G.G.; Zivojnovic, M.; De Smet, A.; Albagli-Curiel, O.; Huetz, F.; Weill, J.-C.; Reynaud, C.-A.; Storck, S. Pms2 and uracil-DNA glycosylases act jointly in the mismatch repair pathway to generate Ig gene mutations at A-T base pairs. J. Exp. Med. 2017, 214, 1169-1180. [CrossRef]

82. Wang, Q.; Kieffer-Kwon, K.-R.; Oliveira, T.Y.; Mayer, C.T.; Yao, K.; Pai, J.; Cao, Z.; Dose, M.; Casellas, R.; Jankovic, M.; et al. The cell cycle restricts activation-induced cytidine deaminase activity to early G1. J. Exp. Med. 2016, 214, 49-58. [CrossRef] [PubMed] 
83. Sharbeen, G.; Yee, C.W.; Smith, A.L.; Jolly, C.J. Ectopic restriction of DNA repair reveals that UNG2 excises AID-induced uracils predominantly or exclusively during G1 phase. J. Exp. Med. 2012, 209, 965-974. [CrossRef]

84. Thientosapol, E.; Bosnjak, D.; Durack, T.; Stevanovski, I.; van Geldermalsen, M.; Holst, J.; Jahan, Z.; Shepard, C.; Weninger, W.; Kim, B.; et al. SAMHD1 enhances immunoglobulin hypermutation by promoting transversion mutation. Proc. Natl. Acad. Sci. USA 2018, 115, 4921-4926. [CrossRef] [PubMed]

85. Thomas-Claudepierre, A.-S.; Schiavo, E.; Heyer, V.; Fournier, M.; Page, A.; Robert, I.; Reina-San-Martin, B. The cohesin complex regulates immunoglobulin class switch recombination. J. Exp. Med. 2013, 210, 2495-2502. [CrossRef] [PubMed]

86. Boboila, C.; Alt, F.W.; Schwer, B. Classical and alternative end-joining pathways for repair of lymphocyte-specific and general DNA double-strand breaks. Adv. Immunol. 2012, 116, 1-49. [CrossRef]

87. Küppers, R.; Dalla-Favera, R. Mechanisms of chromosomal translocations in B cell lymphomas. Oncogene 2001, 20, 5580-5594. [CrossRef]

88. Leder, P.; Battey, J.; Lenoir, G.; Moulding, C.; Murphy, W.; Potter, H.; Stewart, T.; Taub, R. Translocations among antibody genes in human cancer. Science 1983, 222, 765-771. [CrossRef]

89. Robbiani, D.F.; Nussenzweig, M.C. Chromosome translocation, B cell lymphoma, and activation-induced cytidine deaminase. Annu. Rev. Pathol. Mech. Dis. 2013, 8, 79-103. [CrossRef]

90. Pasqualucci, L.; Neumeister, P.; Goossens, T.; Nanjangud, G.; Chaganti, R.S.K.; Küppers, R.; Dalla-Favera, R. Hypermutation of multiple proto-oncogenes in B-cell diffuse large-cell lymphomas. Nat. Cell Biol. 2001, 412, 341-346. [CrossRef]

91. Fujita, T.; Fujii, H. Direct identification of insulator components by insertional chromatin immunoprecipitation. PLoS ONE 2011, 6, e26109. [CrossRef]

92. Rush, J.S.; Fugmann, S.D.; Schatz, D.G. Staggered AID-dependent DNA double strand breaks are the predominant DNA lesions targeted to $\mathrm{S}$ in Ig class switch recombination. Int. Immunol. 2004, 16, 549-557. [CrossRef]

93. Chen, J.-M.; Cooper, D.N.; Chuzhanova, N.; Férec, C.; Patrinos, G.P. Gene conversion: Mechanisms, evolution and human disease. Nat. Rev. Genet. 2007, 8, 762-775. [CrossRef] [PubMed]

94. Lin, W.C.; Desiderio, S. Cell cycle regulation of V(D)J recombination-activating protein RAG-2. Proc. Natl. Acad. Sci. USA 1994, 91, 2733-2737. [CrossRef] [PubMed]

95. Pontarin, G.; Fijolek, A.; Pizzo, P.; Ferraro, P.; Rampazzo, C.; Pozzan, T.; Thelander, L.; Reichard, P.A.; Bianchi, V. Ribonucleotide reduction is a cytosolic process in mammalian cells independently of DNA damage. Proc. Natl. Acad. Sci. USA 2008, 105, 17801-17806. [CrossRef]

96. D'Angiolella, V.; Donato, V.; Forrester, F.M.; Jeong, Y.-T.; Pellacani, C.; Kudo, Y.; Saraf, A.; Florens, L.; Washburn, M.; Pagano, M. Cyclin F-mediated degradation of ribonucleotide reductase M2 controls genome integrity and DNA repair. Cell 2012, 149, 1023-1034. [CrossRef]

97. Hu, C.-M.; Yeh, M.-T.; Tsao, N.; Chen, C.-W.; Gao, Q.-Z.; Chang, C.-Y.; Lee, M.-H.; Fang, J.-M.; Sheu, S.-Y.; Lin, C.-J.; et al. Tumor cells require thymidylate kinase to prevent dUTP incorporation during DNA repair. Cancer Cell 2012, 22, 36-50. [CrossRef]

98. Niida, H.; Katsuno, Y.; Sengoku, M.; Shimada, M.; Yukawa, M.; Ikura, M.; Ikura, T.; Kohno, K.; Shima, H.; Suzuki, H.; et al. Essential role of Tip60-dependent recruitment of ribonucleotide reductase at DNA damage sites in DNA repair during G1 phase. Genes Dev. 2010, 24, 333-338. [CrossRef]

99. Tanaka, H.; Arakawa, H.; Yamaguchi, T.; Shiraishi, K.; Fukuda, S.; Matsui, K.; Takei, Y.; Nakamura, Y. A ribonucleotide reductase gene involved in a p53-dependent cell-cycle checkpoint for DNA damage. Nature 2000, 404, 42-49. [CrossRef] [PubMed]

100. Watt, D.L.; Buckland, R.J.; Lujan, S.A.; Kunkel, T.A.; Chabes, A. Genome-wide analysis of the specificity and mechanisms of replication infidelity driven by imbalanced dNTP pools. Nucleic Acids Res. 2015, 44, 1669-1680. [CrossRef]

101. Bertocci, B.; De Smet, A.; Weill, J.-C.; Reynaud, C.-A. nonoverlapping functions of DNA polymerases Mu, Lambda, and Terminal Deoxynucleotidyltransferase during immunoglobulin V(D)J recombination in vivo. Immunity 2006, 25, 31-41. [CrossRef]

102. Zelensky, A.; Schimmel, J.; Kool, H.; Kanaar, R.; Tijsterman, M. Inactivation of Pol $\theta$ and C-NHEJ eliminates off-target integration of exogenous DNA. Nat. Commun. 2017, 8, 66. [CrossRef] [PubMed]

103. Yousefzadeh, M.J.; Wyatt, D.; Takata, K.-I.; Mu, Y.; Hensley, S.C.; Tomida, J.; Bylund, G.O.; Doublie, S.; Johansson, E.; Ramsden, D.; et al. Mechanism of suppression of chromosomal instability by DNA polymerase POLQ. PLoS Genet. 2014, 10, e1004654. [CrossRef]

104. Wyatt, D.; Feng, W.; Conlin, M.P.; Yousefzadeh, M.J.; Roberts, S.A.; Mieczkowski, P.; Wood, R.; Gupta, G.P.; Ramsden, D.A. Essential roles for polymerase $\theta$-mediated end joining in the repair of chromosome breaks. Mol. Cell 2016, 63, 662-673. [CrossRef]

105. Babbe, H.; McMenamin, J.; Hobeika, E.; Wang, J.; Rodig, S.J.; Reth, M.; Leder, P. Genomic instability resulting from Blm deficiency compromises development, maintenance, and function of the B cell lineage. J. Immunol. 2009, 182, 347-360. [CrossRef] [PubMed]

106. Lim, J.; Giri, P.K.; Kazadi, D.; Laffleur, B.; Zhang, W.; Grinstein, V.; Pefanis, E.; Brown, L.M.; Ladewig, E.; Martin, O.A.; et al. Nuclear proximity of Mtr4 to RNA exosome restricts DNA mutational asymmetry. Cell 2017, 169, 523-537.e5. [CrossRef] [PubMed]

107. De Almeida, C.R.; Dhir, S.; Dhir, A.; Moghaddam, A.E.; Sattentau, Q.; Meinhart, A.; Proudfoot, N.J. RNA helicase DDX1 converts RNA G-quadruplex structures into R-loops to promote IgH class switch recombination. Mol. Cell 2018, 70, 650-662.e8. [CrossRef] [PubMed]

108. Pieper, K.D.; Tan, J.; Piccoli, L.; Foglierini, M.; Barbieri, S.; Chen, Y.; Silacci-Fregni, C.; Wolf, T.; Jarrossay, D.; Anderle, M.; et al. Public antibodies to malaria antigens generated by two LAIR1 insertion modalities. Nature 2017, 548, 597-601. [CrossRef] [PubMed] 